\title{
Chairil Anwar's Recontruction Poetry "Love is Away in The Islands" by Chairil Anwar Becomes a Short Story "Love in The Middle of The Island" by Ahmad Ridwan Hasibuan
}

\author{
Ahmad Ridwan Hasibuan ${ }^{1}$, Rahmat Kartolo ${ }^{2, *}$, Siti Hajarianti Nursyam, Rafidah ${ }^{1}$, \\ Ovy Rizki Ramadhani ${ }^{1}$, and Rahmat Afandi Dongoran ${ }^{1}$
}

${ }^{1}$ Postgraduate Universitas Muslim Nusantara Al Washliyah Medan, Indonesia

${ }^{2}$ Lecturer Universitas Muslim Nusantara Al Washliyah Medan, Indonesia

*Corresponding author email: rahmatkartolo@ umnaw.ac.id

\begin{abstract}
This research aimed at describing the pre-written poetry text "Cintaku Jauh di Pulau" by Chairil Anwar. He wanted to create a short story based on the pre-written poem "Cintaku Jauh di Pulau" was written by Ahmad Ridwan Hasibuan. This research used a qualitative method of development with planning techniques, identification, implementation of development by paraphrasing, identifying based on the mandatory structures in poetry, and evaluating. After the elements of the poetry were verified as true, the researchers continued by developing the paraphrase text of the poetry to become a short story called "Cintaku di Tengah Pulau" by Ahmad Ridwan Hasibuan. The short story creation was verified to Tiflatul Husna; he was the winner of the North Sumatra folklore writing competition in 2017 who was awarded the "Muri" record certificate.

Short stories are created with development techniques based on every word, phrase and clause contained in the poem "Cintaku Jauh di Pulau" by Chairil Anwar. The short story has the same theme but the location of the story is in a village near the sea and a city in Medan. The short story Cintaku di Tengah Island is a bustling city because the author Ahmad Ridwan Hasibuan is a person who has lived in an era of globalization. Then tested and verified the truth of the short story elements to the experts based on the truth of the intrinsic element content of the poetry which is sourced from the book collection of poetry by Chairil Anwar entitled "I Am A Bitch Animal" published by PT. Gramedia. The conclusion in this study is that there are two things: the content of the poem "Cintaku Jauh di Pulau" tells of life's disappointments due to unattainable ideals. Fate snatched the path to achieve that goal. Before achieving his goal, it turns out that death comes first. The lesson that can be taken in the short story "My Love in the Middle of the Island" is that we should not waste people who love us and never see wealth as the main goal in life, because it can bring harm to oneself.
\end{abstract}

Keywords: Decision-Making, poem, Short stories 


\section{INTRODUCTION}

Literary works are created by writers to convey ideas, ideas, experiences, and the mandate of life to society. Literary works are written in the form of fiction or nonfiction so that people can take lessons from the literary work. All literary works will be related to the dynamics of a society's life, and certain traditions, for example, a poem created by a writer [1]-[2]. As for what is included in literature, namely poetry [3]-[7], short stories [8]-[11], novels, romances, fairy tales, dramas, legends, rhymes, gurindam, and others.

According to E. Kosashi [12], literature means good writing or beautiful writing. One of the literary works that still exist today is poetry. The development of Indonesian poetry is essentially a picture of human development in Indonesia. The poet's sensitivity to problems is also likely to illustrate the development of this vision. According to E. Kosashi [12], poetry is a form of literary work that uses beautiful words that are rich in meaning. The beauty of a poem is caused by the diction, figure of speech, rhyme and rhythm contained in the literary work.

In this day and age, if we look at it, there is very little public interest in literature, especially in poetry. The progress of the times and increasingly modern technology have changed the interest in society, especially among teenagers, to love literary works in Indonesia. Moreover, old poetry such as the poetry of one of the famous literary figures of generation 45, Chairil Anwar.

Therefore, the researcher here wants to attract the public's interest by raising one of the poems from Chairil Anwar's work entitled "My Love is Far in the Island" where the poem in the poem tells the theme of life's disappointment because of unattainable ideals. Fate snatched the path to achieve that goal. Before achieving his goal, it turns out that death comes first. Become a short story by the researcher himself entitled "My Love in the Middle of the Island". The reason the researcher wants to write a short story with the theme of Chairil Anwar's own poetry is so that readers can better understand the meaning of the poem "Cintaku Jauh di Pulau" by Chairil Anwar. In addition, to make it easier for readers to understand one of Chairil Anwar's poems, entitled "Cintaku Jauh di Pulau" by reading my short story entitled "Cintaku di Tengah Pulau". Based on the background of the problem above, we can formulate the problems in this study as follows.

1. How is the text of the poem "Cintaku Jauh di Pulau" based on the preface?

2. What is the form of the short story text based on the reconstruction of the poem "Cintaku Jauh di Pulau"?

Besides, purposes of the research are as follows.

1. Want to describe the preface of the poem text "Cintaku Jauh di Pulau".

2. Want to describe the form of the short story text based on the pre-written poetry text "Cintaku di Tengah Pulau".

\section{METHODOLOGY}

This research design is a qualitative research development. In qualitative research, development can be interpreted as a scientific way to research, design, produce and test products that have been produced by Sugiono [13]. According to Sugiono [13], this research uses the level four development methods by researching and developing products and creating products new. Through creative development, namely creating new products that have never existed before, to create the result of Chairil Anwar's poem "Cintaku Jauh di Pulau" by Chairil Anwar into short stories "Cintaku di Tengah Pulau" by Ahmad Ridwan Hasibuan.

\section{RESULTS AND DISCUSSION}

\subsection{Results}

Reconstruction is the return of something to its original place, the compilation or redrawing of existing materials and rearranged as it was or the original incident. So that the meaning of the word reconstruction is returning back or redrawing. Poetry is defined as a builder, builder or maker because basically by creating a poem, a poet has built, created, or formed a new world, physically and mentally. As for this research, looking for a preface of the poem Cintaku Jauh di Pulau by Chairil Anwar so that we will know the meaning contained in it. After knowing its meaning, I as a researcher will reconstruct the poem Cintaku Jauh di Pulau into a short story by myself.

\subsubsection{Presentation of Phases Based on Poetry}

\section{My love is Deep on the Island}

My love is deep on the island, cute girl, now on your own.

The boat goes up, the moon is shining around the neck I put souvenirs for the girlfriend the wind helps, the sea is bright, but feels I won't reach him. In the still water, in the wind At the end of the day everything drove.

Doomed on the throne, saying: "Just aim the boat at my lap".

Hey! The road I've been on for years! The boat together is crumbling! Why does death call first

Before I could cuddle with my love

My sweetheart deep on the island, If I die. He died on his own Deru Campur Debu by Chairil Anwar [14]

The poem "Cintaku Jauh di Pulau" shows the theme of life's disappointment because of unattainable goals. Fate snatched the way to achieve that goal. Before achieving his goal, it turns out that death comes first. 
Table 1 Poetry Texts and Poetry Paraphrases about Love

\begin{tabular}{|c|c|c|}
\hline No & Verse Poem & Poem Paraphrase \\
\hline 1 & $\begin{array}{l}\text { My love is } \\
\text { deep on the } \\
\text { island }\end{array}$ & $\begin{array}{l}\text { This verse describes the poet's } \\
\text { lover who is on an island far } \\
\text { away from him. }\end{array}$ \\
\hline 2 & $\begin{array}{l}\text { Cute girl, now } \\
\text { on your own }\end{array}$ & $\begin{array}{l}\text { This verse depicts the poet's } \\
\text { lover who is still playing on his } \\
\text { own because the poet has not } \\
\text { been able to achieve it. }\end{array}$ \\
\hline 3 & $\begin{array}{l}\text { The boat goes } \\
\text { up, the moon } \\
\text { is shining }\end{array}$ & $\begin{array}{l}\text { This stanza describes the poet's } \\
\text { attempt to reach his lover with } \\
\text { very high hopes and hopes for } \\
\text { the beauty behind it all. }\end{array}$ \\
\hline 4 & $\begin{array}{l}\text { I put a } \\
\text { souvenir for } \\
\text { the girlfriend }\end{array}$ & $\begin{array}{l}\text { This stanza describes the capital } \\
\text { of the poet's preparation for his } \\
\text { beloved lover. }\end{array}$ \\
\hline 5 & $\begin{array}{l}\text { The wind } \\
\text { helped, the sea } \\
\text { was bright but }\end{array}$ & $\begin{array}{l}\text { This stanza describes everything } \\
\text { that helps the poet's struggle to } \\
\text { get his lover. }\end{array}$ \\
\hline
\end{tabular}

6 I won't get to him

\section{$7 \quad$ In the still} water, in the wind

8 At the end of the day everything drove

9 Doomed on the throne, saying

10 "Aim the boat at the lap only"

11 Hey! The road I've been on for years!

12 The boat together is crumbling!

13 Why does death call first

14 Before I could cuddle with my love

15 My sweetie deep on the island

16 If I die, he dies on his own
This stanza describes the heart of the poet who has given up hope because he is unable to reach his lover.

This verse describes the journey of the poet's struggle in reaching his lover who is full of obstacles. This verse describes the poet's efforts to reach the end in order to reach out to his lover.

This stanza illustrates that it turns out that the fate of death is more powerful than all the efforts of the poet.

This verse illustrates that death calls the poet to come to him and does not need to continue his struggle to reach his lover.

This stanza describes the poet's struggle for so long and long to go through.

This verse describes the struggle with the lover so far it must end just like that.

This stanza describes the poet's disappointment because death must come first.

This stanza illustrates that the poet was disappointed because he had to die before he could reach his lover.

This stanza describes the poet's lover who is on an island far from the poet.

This stanza illustrates that if the poet dies, the hope of being able to reach his lover will just die and all hopes and efforts that have been attempted by the poet will disappear.

The table above contains 16 lines of poetry that have been pre-preformed without deviating from the original text of the poem "Cintaku Jauh di Pulau" by Chairil Anwar.

\subsubsection{Short Story Reconstruction Based on Poetry Paraphrase}

The researched poetry development to be a reconstructed short story by paraphrasing, identifying based on the mandatory structure in the poetry, and evaluating. After the elements of the poetry were verified as true, the researchers continued by developing the paraphrasing text of the poetry to become a short story called "Cintaku di Tengah Pulau" by Ahmad Ridwan Hasibuan. The short story has the same theme, but the location of the story is in a village near the sea and a city in Medan. The short story Cintaku di Tengah Island is a bustling city because the author Ahmad Ridwan Hasibuan is a person who has lived in an era of globalization. The following is a verified short story from his reconstruction.

\section{My Love is in the Middle of the Island}

That night, the roar of the waves hit the rocks by the sea. The sound seemed to penetrate Raga's bedroom window and force it into her ear. It was ringing in Raga's mind as if the hometown where she lived was trying hard to throw her away. Raga is the eldest son of the Raja and Marini couple, who daily use the proceeds of the marine wealth on Nias Island to make a living. He has a younger sister named Lolita who is still in high school. Raga is a handsome young man who is covered with white skin, eyes that are not too round, hair that is quite dense and he is quite tall. The clock showed 01.00 PM and Raga began to close her eyes because tomorrow will be far away.

"Are you sure you want to leave, son?" asked Mother Raga hoarsely.

"I'm sure, Mom," replied Raga with confidence as she stepped her foot and left her hometown.

That morning the sun was seen shining cheerfully and painted the shadow of a man walking on a boat to anchor to Sibolga. The ship began to sail the ocean with spoiled waves that accompanied Raga's reverie on the ship. With a strong determination, Raga prefers to migrate to Medan City to try her luck instead of helping her father look for fish in the village. About 12 hours of travel over the sea, Raga's ship begins to dock in Sibolga City. It was dark and Raga immediately asked the local residents whether there was still a bus or metro trip to Medan because Raga had no relatives in Sibolga. However, because it was already evening, Raga chose to rest at the port. As the night starts to get late, Raga stares blankly at the ocean with a thousand dreams, hoping to live happily overseas. He did not want to disappoint his father and mother, hoping to help them with their own burdens, and hoped 
that his uncle who would be visited in Medan would immediately find a job for him.

A week has passed. Raga back and forth to play with her cellphone to delete all messages from Eve while waiting for customers who came to cut. Not long after that a boy came to his barber shop. The style is really very messy, wrapped in a dirty high school uniform the child enters and immediately sits on a barbershop.

"Please trim the sides first, Bang," said the boy.

"Okay, ready to execute!" replied Raga while getting up and preparing the tools. Like most customers, after finishing the pruning, the boy paid him a fee and then hurried off to leave. A few hours after that, a woman with bulging and angry eyes came to Raga. Suddenly Raga was confused.

"I don't want to know, just please, brother, trim my little brother," only after seeing the boy who had been trimmed out of the car Raga understood what that woman meant. "I don't want to know, just please, brother, trim my little brother," only after seeing the boy who had been trimmed out of the car Raga understood what that woman meant. "My little brother is really difficult to manage, Bang. But if I were at the same time, I wouldn't dare to fight, because no one would give me pocket money anymore," said the beautiful girl who had been sedating Raga's eyes with her fashionable style. "Ha ha ha. What nonsense, this brother! " Raga replied with a relaxed laugh.

"Whatever, this brother. No need to call, Brother. Just Clara. " said the girl as she introduced her name.

As time went on, Raga and Clara grew closer to each other. Although actually Raga doesn't really like some of the arrogant, arrogant, and doesn't respect Clara's man, but still Raga loves Clara.

"Uncle, tomorrow Raga wants to return to the village,"

"Haah! Suddenly Uncle Raga was shocked to hear Raga's words. Raga immediately returned to the room and left a puzzled expression on her uncle who was still silent in amazement. After a long journey Raga arrived at her beloved village. His mother was surprised because Raga had not contacted him before.

"Why didn't you notify me first, son?" asked Mother Raga in surprise.

"It's okay, Mom. There are things that you have to solve here," Raga replied with a thousand faces that kept a secret.

$$
* * *
$$

Raga also met Eve and they sat together under a coconut tree right in front of Eve's house. "I want to apologize to you, I realized that I love you. In two weeks, we are married, okay! " Raga glared at Eve. Suddenly Eve was surprised to hear Raga's expression. His heart was really happy and touched because of the feelings he had been harboring were also reciprocated.

"Why are you silent?" asked Raga, staring at Eve's cheeks that began to turn red.

"Yes, I want to accept you, Bang." replied Eve briefly with incomparable joy. A week had passed and their wedding preparations were almost complete. Not long after that Raga immediately went to Eve's house.

"Honey," said Raga softly.
"Yes, dear," said Eve, full of surprise at the look on Raga's unusual face.

"I want to give you a wonderful gift. I need another 5 million to buy the gift. Can I borrow your money first, honey? "Raga explains his special intentions to Eve.

"Yes, dear," replied Eve with a sweet smile.

"Thank you, my dear." said Raga so happily. Eve went into the house to get the money. That morning the weather was a bit drizzling. Step by step Raga started to leave her house secretly. It turned out that Raga was just doing tricks to get money. That morning Raga immediately left for the port and moved to Medan City. The next day at nightfall, Raga arrived in Medan. The next day Raga went to a jewelry shop to find the necklace that Clara wanted. Without thinking, Raga bought the necklace and immediately rushed over to Clara's house. But the unexpected happened. Raga saw Clara chatting and making out with other men on the porch of her house.

"What is this?" asked Raga.

"This is my future husband. Don't dream of you marrying me. It will never happen. " how broken Raga's heart to hear Clara's answer. It turns out that all this time he has only been used for pleasure. Raga was really disappointed and chose to leave Clara's house before her emotions ran high. It was getting late and Raga arrived at her uncle's house.

"Where have you been Raga?" asked his uncle in surprise, seeing Raga's face gloomy too. Raga didn't answer anything. He went straight into the room. Raga also lay on her bed while remembering the incident this afternoon. He really did not think this could happen to him. Suddenly Raga remembered the image of a girl who had always been neglected. Raga also opened her cellphone which had not been activated. So many missed calls from Eve and her family.

$$
* * *
$$

The next day when the sun began to rise Raga said goodbye to her uncle and hurried off to the terminal. And in the evening Raga arrived at the Port of Sibolga City. That night the ferry started moving from Sibolga to Nias Island. The moon looks so bright in the sky. Illuminate the shadow of a man relaxing on the roof of a ship with a jewelry necklace tied around his neck. The necklace will be presented to Eve according to her promise the other day. Soon Raga hears a commotion from inside the ship. The body goes down and goes inside. It turned out that there was serious damage to the ship's engine and the ship mechanics inside began to panic. The clock showed 01.00 in the evening and many of the passengers were fast asleep. There was the sound of lightning and the sea breeze getting stronger. Unexpectedly, the weather at sea was getting worse. Finally, the passengers started to panic. However, the crew tried to calm them down. Not much different from Raga who is getting pale.

Raga is very afraid if unwanted things happen. Suddenly Raga's heart began to beat faster. It feels that Raga will not live up to her expectations. Raga continues to ask her heart whether all the struggles she has been facing have to end tonight? In his heart kept whispering whether this is the end point of his struggle? Shortly after Raga fell 
silent, one of the crew gave him a life jacket and woke Raga from his reverie. He just realized that the entire ship was starting to panic. The ship began to roll right and left irregularly. Raga begins to surrender with all hopes when it turns out to be death. Even in the midst of a storm that is getting stronger, she cannot control her body which is being devoured by the big waves. And in the end, Raga sank with all the hopes that had been fought for. He had died before he could reach his love. His hopes have vanished to reach the cute girl on the island there. After Raga's death, all of Eve's hopes will die.

Table 2 The form of short story text is based on its reconstruction from poetry

\begin{tabular}{|c|c|c|}
\hline No & Verse Poem & $\begin{array}{l}\text { The form of short story text is } \\
\text { based on its reconstruction from } \\
\text { poetry }\end{array}$ \\
\hline 1 & $\begin{array}{l}\text { My love is } \\
\text { deep on the } \\
\text { island }\end{array}$ & $\begin{array}{l}\text { Paragraph } 14 \text { line } 43 \text { "Oh, my } \\
\text { lover who is far away on the } \\
\text { island. }\end{array}$ \\
\hline 2 & $\begin{array}{l}\text { Cute girl, } \\
\text { now on your } \\
\text { own }\end{array}$ & $\begin{array}{l}\text { 14th paragraphs } 43 \text { rd and } 44 \text { th The } \\
\text { cute girl who is still alone waiting } \\
\text { for me because she can't have you } \\
\text { yet. }\end{array}$ \\
\hline 3 & $\begin{array}{l}\text { The boat } \\
\text { goes up, the } \\
\text { moon is } \\
\text { shining }\end{array}$ & $\begin{array}{l}\text { Paragraph } 15 \text { lines } 1,2,3,4 \text { and } 5 \\
\text { The next day when the sun started } \\
\text { to rise Raga said goodbye to her } \\
\text { uncle and hurried off to the } \\
\text { terminal. And in the evening Raga } \\
\text { arrived at the Port of Sibolga City. } \\
\text { That night the ferry started moving } \\
\text { from Sibolga to Nias Island. The } \\
\text { moon looks so bright in the sky. }\end{array}$ \\
\hline 4 & $\begin{array}{l}\text { I put a } \\
\text { souvenir for } \\
\text { the girlfriend }\end{array}$ & $\begin{array}{l}\text { 15th paragraphs } 5 \text { th and 6th lines } \\
\text { illuminate the shadow of a man } \\
\text { relaxing on the roof of a ship with } \\
\text { a jewelery necklace tied around his } \\
\text { neck. }\end{array}$ \\
\hline 5 & $\begin{array}{l}\text { The wind } \\
\text { helped, the } \\
\text { sea was } \\
\text { bright but } \\
\text { felt }\end{array}$ & $\begin{array}{l}\text { Paragraph } 16 \text { line } 1 \text { and } 2 \text { Day is } \\
\text { getting late at night. Raga still } \\
\text { feels at home staring at the ocean } \\
\text { from the roof of the ship even } \\
\text { though the wind is getting cold and } \\
\text { blowing hard. }\end{array}$ \\
\hline 6 & $\begin{array}{l}\text { I won't get } \\
\text { to him }\end{array}$ & $\begin{array}{l}\text { The 16th paragraphs } 2,3,4,5 \text {, and } \\
6 \text { lines. Not long after, Raga heard } \\
\text { a boisterous voice from inside the } \\
\text { ship. The body goes down and } \\
\text { goes inside. It turned out that there } \\
\text { was serious damage to the ship's } \\
\text { engine and the ship mechanics } \\
\text { inside began to panic. The clock } \\
\text { showed } 01.00 \text { in the evening and } \\
\text { many of the passengers were fast } \\
\text { asleep. }\end{array}$ \\
\hline 7 & $\begin{array}{l}\text { In the still } \\
\text { water, in the } \\
\text { wind }\end{array}$ & $\begin{array}{l}\text { 16th paragraphs } 6 \text { th, } 7 \text { th, and } 8 \text { th } \\
\text { lines. There was the sound of } \\
\text { thunder and the sea wind getting } \\
\text { stronger. To my surprise, the }\end{array}$ \\
\hline
\end{tabular}

weather at sea was getting worse. Finally, the passengers started to panic.

8 At the end of Paragraph 16 lines 11, 12, 13, 14. the day and 15 Suddenly my body's heart everything beats faster. It feels that Raga will drove not live up to her expectations. Raga continues to ask her heart whether all the struggles she has been facing have to end tonight? In his heart kept whispering whether this is the end point of his struggle?

9 Doomed on The 16th paragraphs 17th and 18th the throne, lines, the ship began to tilt to the saying right and to the left irregularly.

10 "Aim the The 16th paragraphs 18th and 19th boat at the lines of the body began to lap only"

11 Hey! The road I've been on for years! surrender with all hope if it turned out that death had approached him first.

The 16th paragraphs, 20th, 22nd, and 23rd paragraphs Slowly his tears mingled with the rain, which increasingly dominated the sea that night. Raga is sad to remember that the life struggle that has been through for years must stop.

12 The boat The 16th paragraph, the 24th, 25th, together is and 26th lines of the Body and crumbling! Body are bobbing in the ocean. Raga also gave up hope and was sure that her struggle with Eve would be weak tonight.

13 Why does The 16th paragraphs, lines 26 and death call 27, did not think that death took first away all his hopes.

14 Before I 16th paragraphs 29th and 30th line could cuddle and in the end the body sank with with my love all the hopes that had been fought for. He died before he could reach his love.

15 My sweetie The 16th paragraphs 30th and 31st deep on the lines. Her hopes are already island reaching the cute girl on the island there.

16 If I die, he Paragraph 16 lines 31 and 32 After dies on his the body dies all hope of Eve will own die.

Based on the description table of poetry into short stories above, there are 16 lines of poetry that have been reconstructed into the narrative of the short story "Cintaku di Tengah Pulau” by Ahmad Ridwan Hasibuan. 


\subsection{Discussion}

After the short story is recognized by the experts, it will be discussed according to the current short story form. According to Tarigan [15], short stories are the most popular form in Indonesian literature, according to Ellery Sedgwick, saying that short stories are a presentation of a separate situation or a group of circumstances that give a single impression on the reader's soul. A short story should not be filled with unnecessary things or "a shortstory must not be cluttered up with irrelevance" [15] Meanwhile, according to Henry Sciel Camby, among other things, said that "the impression is one and alive, that should be the result of a short story". The characteristics of short stories contained in the reconstruction short stories based on Tarigan [15], namely: the main characteristics of the short stories are: short, coherent, and intensive (brevity, univity, and intensity). The main elements of a short story are: scene, character, and motion, (scene, character, and action). The language of the short story must be sharp, suggestive, and attract attention (insincive, suggestive, and aleart). The short story must contain the author's interpretation of his conception of life, either directly or indirectly.

A short story should have an effect on the reader's mind. A short story should give the reader the feeling that it is the storyline that attracts feelings first, and only then attracts thoughts. The short story contains deliberately chosen details and incidents that can raise questions in the mind of the reader. A short story of an incident that primarily rules the storyline. The short story must have a main actor. Meanwhile, another opinion is that a short story must have an interesting effect or impression. Short stories depend on (one) situation. Short stories give a single impression. Short stories provide roundness of effect. In terms of diction, this short story still uses all the vocabulary contained in the poem. The total poetry vocabulary is 86 words. Styles 12 are generally hyperbole and irony. The number of short story vocabulary is equal to 2183 vocabulary words with hyperbole style. What is the reason why the author uses it because he likes to be excited about life and wants to move forward like the age of metabolism full of material objects. While the author is a person who lives simply, the important thing is to live in peace.

\section{CONCLUSION}

Based on the results of this study, several things can be concluded regarding as follows.

1. The poem "My Love is Deep in the Island" shows the theme of life's disappointment because of unattainable goals. Fate snatched the way to achieve that goal. Before achieving his goal, it turns out that death comes first.

2. The poem "Cintaku Jauh di Pulau" by Chairil Anwar can be reconstructed into a short story "Cintaku di Tengah Pulau” by Ahmad Ridwan Hasibuan.
3. The short story reconstruction "Cintaku di Tengah Pulau" by Ahmad Ridwan Hasibuan has fulfilled the structure of the short story according to the verification result of Tiflatul Husna.

\section{REFERENCES}

[1] E. Ismawati, Nationalism in Indonesian Literature as Active Learning Material. International Journal of Active Learning, 3 (1) (2018), 33-48

[2] M. Firdaus, Y. Telaumbanua, The Current Condition of Indonesian Literature Teachers: A Study about Student's Constraints in Learning Writing Creative Literature. International Journal of Research in Counseling and Education, 2 (2) (2018), 71-76.

[3] S. M. Khrais, Art and Poetry: The Power of Form. Journal of Language and Literature, 4 (2) (2013), 106 114.

[4] N. D. Irmawati, Understanding how to Analyze Poetry and its Implication to Language Teaching. International Journal on Studies in English Language and Literature, 2 (11) (2014), 35-45.

[5] N. Herlina, Teaching Literature Through Poetry: A Shifting Reading Orientation from Efferent to Aesthetic. Journal of English Education, Literature, and Culturem 1 (2) (2016), 225-238.

[6] K. A. Anindita, S. Satoto, Sumarlam, Diction in Poetry Anthology Surat Kopi by Joko Pinurbo as A Poetry Writing Teaching Material. International Journal of Active Learning, 2 (1) (2017), 39-49.

[7] D. Syafitri, M. Marlinton, An Analysis of Figurative Language Used in Edgar Allan Poe's Poems. Linguistic, English Education and Art (LEEA) Journal. 2 (1) (2018), 43-59.

[8] A. E. Frimasary, Using Short Story to Improve Student's Reading Comprehension (A Study at the Second Year Student of SMPN 2 Kota Bengkulu). Journal of Linguistics and Language Teaching, 2 (2) (2015), 8 pages.

[9] S. A. Alami, The Power of Short Stories, Novellas and Novels in Today's World. International Journal of Language and Literature, 4 (1), (2016), 21-35.

[10] Hasbaini, A. Manan, Teaching Reading Comprehension by Using Short Stories. English Education Journal, 8 (3) (2017), 404-423.

[11] M. Basseler, C. Reynier, Re-framing the Modernist Short Story: Introduction. Journal of the Short Story in 
English, 64 (2015), online: March 1, 2017, connection: December 3, 2020, 5 pages.

[12] E. Kosasih, Ketatabahasaan dan Kesusastraan, cetakan keenam. Bandung: Yrama Widya, 2011.

[13] Sugiono, Metode Penelitian \& Pengembangan, cetakan ketiga. Bandung: ALFABETA, 2017.

[14] C. Anwar, Poetry Chairil Anwar Collections, Jakarta: Dian Rakyat, 1995.

[15] G. H. Tarigan, Prinsip-Prinsip Dasar Sastra. Bandung: Angkasa, 2014.

[16] N. Notosusanto, Cerita Pendek dalam Sastra Indonesia Modern; dalam Kenangan Dies Natalis VII Fakultas Sastra Universitas Indonesia. Jakarta: Universitas Indonesia, 1957. 